\title{
IoT皮膚コンダクタンス測定器を用いた授業評価
}

\author{
長野 祐一郎 (文京学院大学人間学部) \\ 永田 悠人 (文京学院大学大学院人間学研究科) \\ 宮西 祐香子 (早稲田大学大学院人間科学研究科) \\ 長濱＼cjkstart澄（東京工業大学教育革新センター） \\ 森田裕介 (早稲田大学人間科学学術院)
}

\section{Class Evaluation Using IoT Skin Conductance Measuring Instruments}

\author{
Yuichiro NAGAno (Department of Human Studies, Bunkyo Gakuin University) \\ Yuto NagATA (Graduate School of Human Studies, Bunkyo Gakuin University) \\ Yukako MiYANISHI (Graduate School of Human Sciences, Waseda University) \\ Toru Nagahama (Center for Innovative Teaching and Learning, Tokyo Institute of Technology) \\ Yusuke Morita (Faculty of Human Sciences, Waseda University)
}

We measured the skin conductance and subjective scales of 48 college students during classes involving conventional lectures, in-class experiments, and discussions. During a lecture, we provided an overview of skin conductance. The in-class experiment consisted of a toy-gun shooting game. The in-class discussion consisted of the social application of psychophysiological measurements. Results indicated that the skin conductance of participants gradually decreased as the lecture progressed, but became remarkably high during the discussion. The subjective assessment of the class by students was generally positive, except for the lecture. The psychophysiological and subjective scale responses of the students were correlated only during in-class experiment, but the correlation was lost during the lecture and the discussion, possibly because of difficulties in the awareness of the level of physiological arousal and the anxiety caused by the interpersonal situation, respectively. The possibilities and problems of applying multi-person measurements of psychophysiological activities in educational settings are discussed.

Key words: electrodermal activity, class evaluation, Internet of Things

2018.12.30受稿，2019.11.20受理，2020.3.14 J-STAGE早期公開，doi:10.5674/jjppp.1903si

連絡者抢よび連絡先：テ356-8533 埼玉県富士見市ふじみ野市亀久保1196 文京学院大学人間学部 長野祐一郎

E-mail: nagano@bgu.ac.jp 
【要 約】 48 人の大学生の皮虐コンダクタンスと主観評価を, 従来型の講義, 授業内実験, およびディスカッシ ヨンを含む授業中に測定した。講義中は, 皮虐コンダクタンスの概要を解説し, 授業内実験では射的ゲームを行 い, ディスカッションは, 精神生理学的測定の社会的応用について行った。参加者の皮虞コンダクタンスは, 講 義が進むにつれて徐々に低下したが，ディスカッション中に著しく高くなった。授業に関する学生の主観的評価 は, 講義を除き概ね肯定的であった。学生の生理的反応と主観評価は, 授業内実験でのみ相関し, 講義とディス カッションでは失われた。自己の覚醒水準の認識が難しいため, 相関が講義中に減少したと考えられた。また, 対人状況によって生じる不安により, ディスカッション中の相関が弱められた可能性があった。教育環境におい て, 精神生理学的活動の多人数測定を適用することの可能性と問題について議論を行った。

\section{はじめに}

Bloom et al. (1971 梶田ら訳 1973) によると, 教 育目標は, 認知的領域, 情意的領域, 精神運動的領域 に分類され，各々の領域ごとに評価を行うことが求め られる。学習評価で広く用いられるテストは，知識や スキルといった学習者の認知的側面を主に評価するも のであり，情意的側面を評価することは難しい（寺 尾, 2012)。精神生理学は, 学習に対する意欲や関 心，態度といった情意領域における評価において，そ の貢献が期待されてきた（中山・清水，2000; 梅沢， 1998)。皮膚電気活動を用いた例では, 講義形式の授 業では生徒の覚醒水準の低下にともない皮虐電位が経 時的に低下することや，授業内における生徒間の相互 作用が促進されると, 皮膚抵抗反応が参加者間で同期 することが見出されている(本間，1984；堀，1986）。 また，皮膚温を用いた事例では，課題難易度が皮膚温 変化量と対応する可能性が報告されている(中山ら, 1998）。視覚系を用いた事例では，TV番組や教育メ ディアに対する興味と, 瞳孔径や瞬目率の関係性が調 べられてきた（浅野ら，1995; 西川・畑内，1998; 清 水ら, 1987)。比較的近年では, eラーニング受講者 を対象に，ストレスコーピングの観点から，心蔵血管 反応を用いた教育コンテンツ評価が行われている (Irfan et al., 2011; 野村ら, 2011; 矢島ら, 2012)。こ のように, 多様な生理指標を用い, 教育場面の評価が 行われてきた。

評価対象となる授業に目を向けると，2016年の中 央教育審議会答申の骨子となるなど，いわゆるアク ティブラーニングの導入が話題を集めつつある。アク ティブラーニングとは「学生の自らの思考を促す能動 的な学習」(溝上, 2007), もしくは「一方的な知識伝
達型講義を聴くという (受動的) 学習を乗り越える意 味での, あらゆる能動的な学習 (溝上, 2014)」と定 義される。具体的には, 問題解決型学習, プロジェク 卜型学習, 反転授業, ワークショップ型, ディベート 型などの形式が含まれ, 多くの大学や高等学校で導入 されつつある。一方, アクティブラーニング型授業に はいくつかの課題が存在する。一つは授業を用意する 教員側の負担が大きくなる事であり, 特にプロジェク ト型やワークショップ型などの学習方法は, 授業担当 者だけでなく，授業進行を様々な面からサポートする ファシリテーターの重要性が指摘されている（安斎・ 青木，2019）。また，グループワークを多く含む反転 授業では, 授業形式に馴染めない学生が一定数存在す ることも報告されている（向後ら，2012）。これらの 授業方式の多くは, 他者とのコミュニケーションを基 盤とするため, 学習者の特性によっては期待通りの成 果を得られない可能性が想定される。生体情報による 学習評価は, 対人場面において過剩な緊張を生じてし まう等の, 受講者の個人的特性を理解し, より適切な 型の授業を提供する助けになる可能性がある。

一見有望に思われる，生体情報による授業評価だ が，現状実施には大きな壁がある。生体計測機器は一 般に高価であり, 操作が難しいため専門的知識を必要 とし，かつ多数を同時に計測するように作られていな い。結果として, 生体情報を用いた授業評価は, 少人 数かつ短時間での検討にとどまるケースが多い。数十 人規模の授業を評価するためには，計測に伴う物的・ 人的コストを大幅に改善する事が求められる。幸い, デジタルファブリケーション技術やフィジカルコン ピューティングの一般化, いわゆるメーカームーブメ ントの台頭により（Anderson, 2012 関訳 2012), 計 測環境デザインのハードルは大きく引き下げられた。 
オープンソース・ハードウェアであるArduinoや， 近 距離通信のセンサーネットワーク, IoT (Internet of Things) 技術を利用した, 低コスト生体計測の試みが 行われている（長野，2012；宮西ら，2017; 櫻井, 2017)。低コストから用途に応じてカスタマイズされ た計測器の導入により, 健康, 教育, エンタテインメ ント等, 様々な領域を対象に, 精神生理学的知見の応 用が期待される。

本研究では, 物的・人的コストの問題をオープン ソース・ハードウェアやIoT 技術の導入により克服す ることで, 従来手薄であった情意面での授業評価を, 多人数対象に実現する事を目的とした。具体的には, 本研究ではIoT対応型計測器50台を作成し, 授業評 価を通し, 計測環境の運用可能性を検討することとし た。その際, 測定指標として, 皮膚コンダクタンス (Skin conductance: 以下 SC とする) を選択した。前 述の皮膚抵抗反応が, 皮膚表面の電気的抵抗を示すも のであるのに対し，SCは流れやすさを示す。SCは， エクリン汗腺の働きと関係し, 交感神経活動の鋭敏な 指標となるため, 学習過程に大きく影響しうる覚醒水 準の指標として, 長く用いられてきた経緯がある（本 多, 2017)。加えて覚醒度に応じて上昇を示すため, 皮虚抵抗に比べ覚醒度との関倸が理解しやすい。ま た, 測定回路が公開されているため, 独自の機器を作 成しやすいなどの利点がある。さらに, 精神生理学な らではのアクティブラーニングとして, 実際に装置を 用いながら測定を行う授業内実験を実施し, 従来型の 講義やアクティブラーニングの典型であるディスカッ ションと比較することとした。

\section{方 法}

\section{実験参加者}

大学生 48 名 (平均年齢 19.75 歳, $\mathrm{SD}=0.63$ ) とした。 性別の構成は, 男性 18 名, 女性30名であった。いずれ も著者の講義を受講する学生であり, 実験系授業にお いて，心電図計測を経験済みであった。参加者には, 期末試験採点時に加点が行われることが告げられた。

\section{実験課題}

著者が行う精神生理学の講義を実験課題として用い た。時間中に, 講義, 授業内実験, ディスカッション
の3期間を設け, それらに参加する学生を対象に, 約 60 分間にわたり心身の反応を測定した。講義は, 皮 膚電気活動に関するものであり, 汗腺の種類とその機 能に関する解説, 測定原理と測定事例, 精神生理学で の位置づけに関する内容を含むものであり約 24 分の 長さであった。授業内実験は, 射的課題中に SC を測 定するものであった。ホワイトボードに描かれた的に 向けて, 銃型玩具で吸盤つきダーツを発射し, 得点を 競いあう内容であった。最初に女子学生のペア, 次に 男子学生のペアが行い, 最後に各ペアの勝者が勝負を 行うという内容であり約23分間の長さであった。 ディスカッションは，SCの測定が身近（低コスト・ コンパクトでどこでも測れる）になると，日常生活の どのようなことに利用可能か, どのようなビジネスが 展開可能かを, 近隣に座っている学生と話し合い, 浮 かんだアイデアをリアクションペーパーに記載すると いうものであり，長さは約 11 分間であった。

\section{実験装置}

計測装置は，金銭的コスト，運用上の人的コストを できる限り削減するようデザインした。さらに，身体 への装着を想定し, 極力サイズを小さく保つよう配慮 した。また, 再生産可能性をも考慮し, ソフトゥェ ア，ハードウェアともに，できる限りオープンソース であるものを用いて構成した。

計測装置は上下段に分割し, 下段には計測用電子回 路㧍よび $\mathrm{AD}$ 変換装置の他, 電池, 電源関連部品を配 置し, 上段にはマイクロコンピュータとユーザーイン ターフェイスを配置した。以下に, 下段, 上段, その 他の順でハードウェアの構成を述べる。

下段部分でSC測定に, 美濃 (1986) に示される回路 を用いたが, 現在の電子部品流通事情にあわせ, 定電 圧出力にLM385Z-1.2(Texas Instruments)を用いた （図1）。増幅は，ブリッジ回路側への影響を抑止する ため, 1段目は入力インピーダンスが高い計装アンプ (Linear Technology, LT1167) を用い, 2段目にはAD変 換の分解能を高く保つためレール toレールのオペアン プ (National Semiconductor, LMC6482)を用いた。こ れらの回路は, 長野・吉田 (2018) で用いたものと同等 であった。増幅回路の電源は, 1 セルのリチウムイオ ン電池 (Keenstone, Model752035) の3.7 Vを, DCDC コンバーター (秋月電子, AE-XCL102D503CR-G) で 


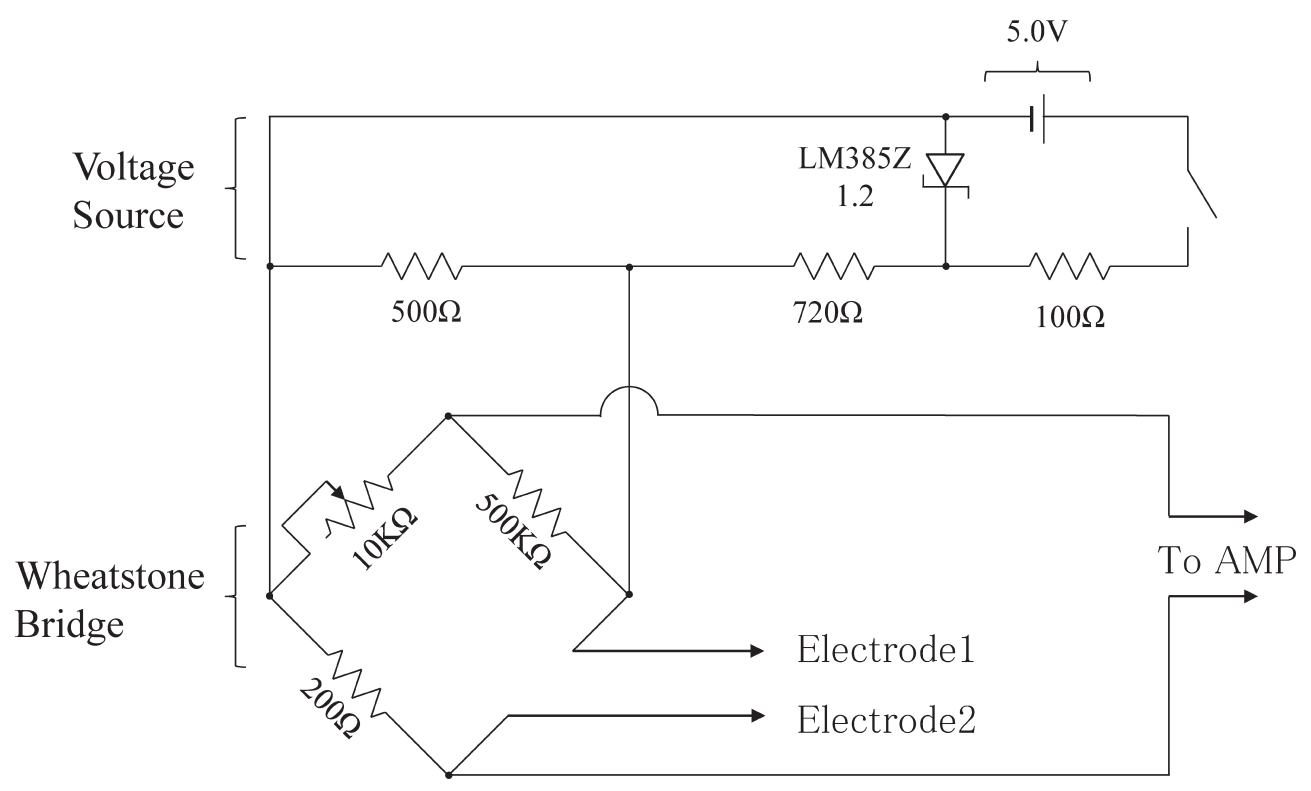

図1. 皮膚コンダクタンスの測定に用いられた回路

$5 \mathrm{~V}$ に昇圧し用いた。さらにレールスプリッタ（Texas Instruments, TLE2426CLP) で分割し， $\pm 2.5 \mathrm{~V}$ の正負 両電源とした。 $\mathrm{AD}$ 変換には, 電圧リファレンス内蔵 で小型化しやすいため, $\mathrm{I} 2 \mathrm{C}$ 接続の $\mathrm{AD}$ 変換装置 (Adafruit, ADS1015)を用いた。

上段には, IoT対応マイクロコンピュータ, マイコ ン内蔵LED (秋月電子, AE-WS2812B) 3個, タクト スイッチ3 個が配置された。マイクロコンピュータは, ESP-WROOM02(秋月電子, AE-ESP-WROOM-02) を用いた。

上段と下段は $2.54 \mathrm{~mm}$ 間隔のピンヘッダー4本を用 いて接続し, 下段の $\mathrm{AD}$ 変換装置で得られた測定值は $\mathrm{I} 2 \mathrm{C}$ 接続によって上段のマイクロコンピュータに送信 した。電子部品類は自作の回路基板を用いて組み 立て, $5 \times 7 \times 1.5 \mathrm{~cm}$ の $3 \mathrm{D}$ プリントされたケースに 収めた。電子回路はEAGLE Ver. 7.5.0 Light Edition (CadSoft) で作成し, 回路基板はCNCルーター (ORIGINALMIND, KitMill CIP100)で作成した。部 品の総額は1台あたりおよそ3,000円であった。

ソフトウェアは, ArduinoIDE1.8.1, ESP8266 Arduino Core Ver2.2.0, Adafruit ADS1X15ライブラリを用い て作成した。 $\mathrm{AD}$ 変換は $12 \mathrm{bit}$ の精度, $1 \mathrm{~Hz}$ のサンプ リング周波数で行った。Wi-Fi使用に起因するノイズ 混入を抑止するため, $\mathrm{AD}$ 変換装置を作動入力方式で 用いた。計測值はNTPサーバー経由で得られたタイ ムスタンプとともに，10秒毎にWi-Fi経由でサーバー
にHTTPプロトコルで送信し， サーバー側でデイスク に記録した。また, 計測装置上面には装置ごとに固有 のURLを表すQRコードが貼り付けられており, ユー ザーは自分のスマートフォンで当該URLを表示する ことにより，直近 10 分間の SC 変化を確認することが できた。この機能は, 実験課題の内容が心身相関に関 する授業であること, 日常生活における生体情報の利 用可能性をディスカッションの議題に設定しているこ とを考慮し追加された。測定者は, サーバー上に蓄積 された計測結果を, $\mathrm{PC}$ 上のブラウザから随時確認す る事ができた。確認用ソフトゥェアは二種類あり, 一 方は参加者の波形を 8 人同時に確認可能なものであ り, 他方は各計測器の電源電圧, 最終アクセスからの 経過時間, SC の瞬時值を50台分同時に確認できるも のであった。これらサーバサーバーサイドのソフト ウェアは, PHP Ver. 5.2.17で作成し, 大学外の商用 サーバー上で運用した。グラフの描画には, Google Chartを利用した。

本研究では, 多人数同時測定時のトータルコストの 低さから, 通信方式にWi-Fiを選定した。ネットワー ク接続環境として, 各計測機との接続に無線LAN ルーターArcher5400 (TP-link)を用いた。当ルー ターは64クライアントを同時に接続可能なもので あった。様々な環境での計測を想定し，上流にLTE 接続型無線LANルーターAterm PA-HT100LN (NEC) を接続し，格安LTE回線を経由してWANに接続し 


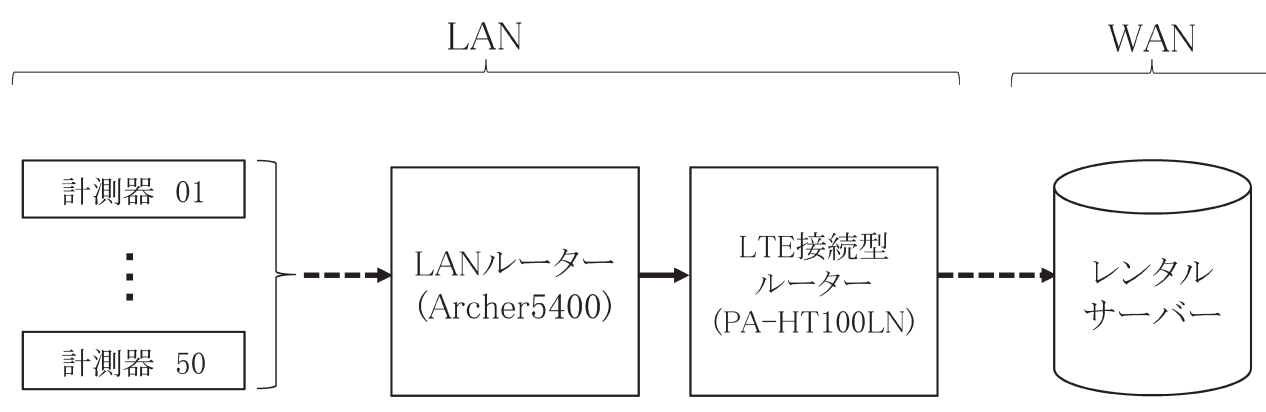

図2．測定に用いたネットワーク環境の構成
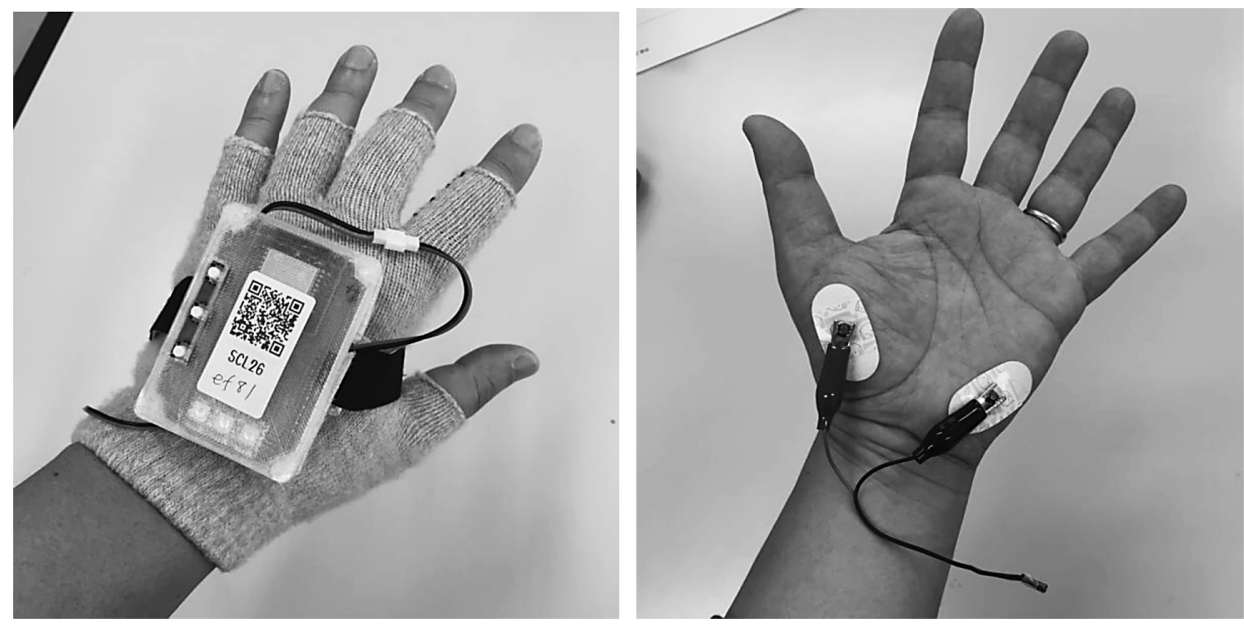

図3。本研究に用いられた測定装置と電極の配置

た。計測器とこれらのネットワーク機器の関係を図 2 に示した。図中破線の矢印は無線接続, 実践の矢印は 有線接続を表す。

\section{主観報告}

授業内容に対する主観評定として, 三保・清水 (2011)の「大学での学習観」尺度を参考にしつつ, 回 答時間が極力短くなるよう, “主体的な”, “受け身な”, “興味深いものである”，“無意味なものである”の4項 目を授業態度の能動, 受動性評価に用いた。さらに, “楽しい”，“活気のある”，“集中した”を授業に対す るポジティブ評価項目として, “眠い”, “だるい”, “授 業が長く感じた”をネガティブ評価項目として加え, 合計 10 項目により授業内容を評定させた。回答はあ てはまらない (1点) から, あてはまる (5 点) の5件法 で求めた。これらの評定は, 各期間終了時に, 参加者 のスマートフォンを用いブラウザ上で行われた。

\section{生理指標}

$\mathrm{SC}$ 測定した。電極は入手性と価格を考慮し, 日
本光電製のVitrode F-150Sを用いた。電極はDawson, Schell, \& Filion (2007) に示される電極装着部位の 内，参加者が両手の指を自由に使える状態を維持する ことを重視し, 非利き手の母子球および小指球を選定 し装着した。その際，電極扔よびみの虫クリップを， 指なし手袋を装着することによって固定し, さらにべ ルクロを用いることで計測器本体を手袋の甲部分に固 定して測定した（図3）。

\section{手続き}

実験参加者は, 講義室入り口付近に設置された箱の 中から, 測定に必要な物品が収められたファスナー付 きビニール袋を取り出し, 自由に教室内に着席した。 袋には, 計測器, ディスポーザブル電極, 電極と本体 を接続するケーブル, 手袋, インフォームドコンセン 卜兼操作マニュアルが封入されていた。授業開始時 に, 教員は実験の趣旨を述べ, 参加者は手元のマニュ アルおよび前方スクリーンで行われる教員の解説に従 い, 各自で装置を非利き手に装着し, 電源スイッチを 入れ，ネットワークへの接続を確認した後計測開始ボ 


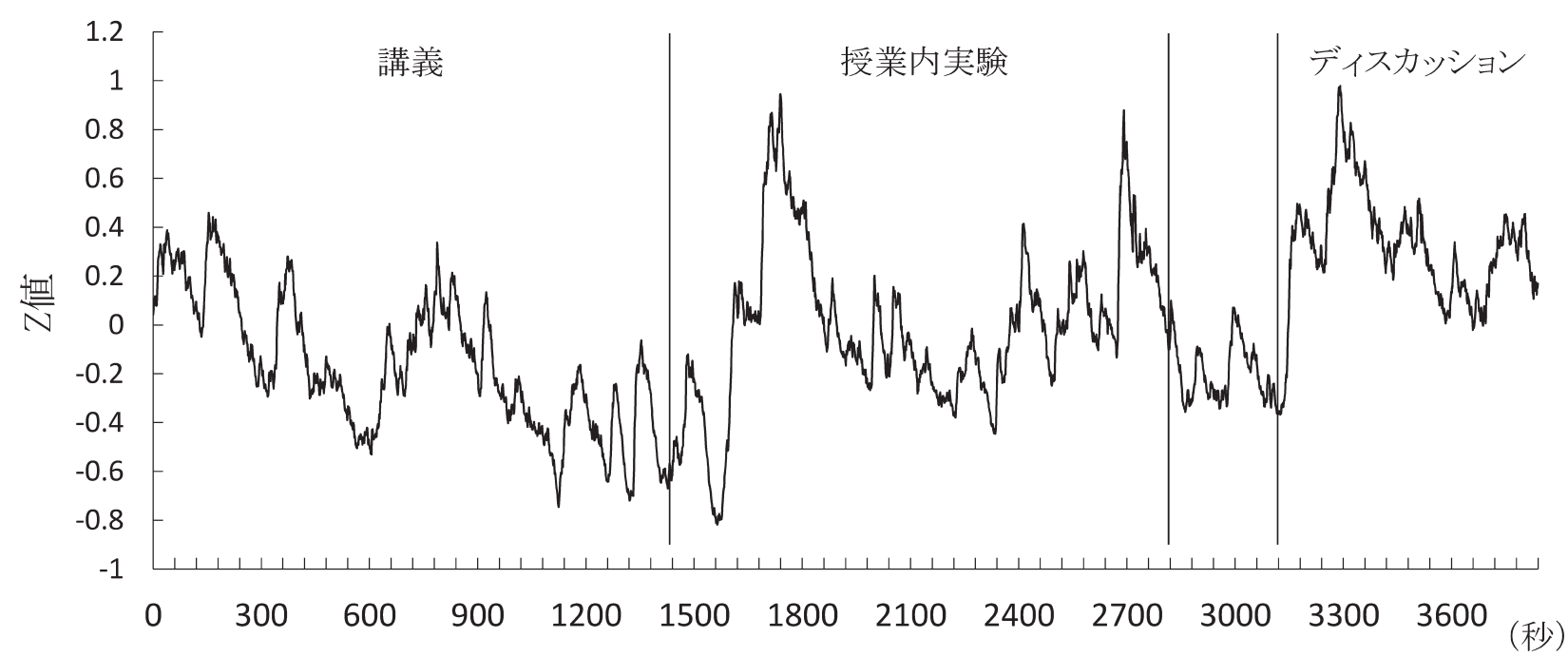

図4. 授業中の各期間に扔ける皮虐コンダクタンス変化

タンを押した。さらに教員は, 計測装置に貼り付けら れている QRコードのアドレスにアクセスすること で，参加者はいつでもスマートフォンを用い，自分の $\mathrm{SC}$ 確認できることを説明した。装着後, 姿勢や体 の動作について, 特に制限を行うような教示は行わな かった。すべての期間を終えた後, 参加者はマニュア ルに従って自ら計測器の電源を切り, とり外し, もと 通りに袋に封入し返却を行った。

講義室には, 計測器および関連ソフトウェアの使い 方を熟知した補助学生が3名同席しており, 計測器か ら送られてくる值を各自のPCでチェックしていた。 值が適切な範囲に入っていない, 途中で停止したなど の際には, 該当する計測器を装着している学生のとこ ろへ移動し, 電極装着位置やケーブル接続状態の チェック, 必要に応じて計測器の再起動を行った。教 室最後部には, 通信用機材一式およびビデオカメラが 設置されており，授業進行の様子が撮影された。

なお, 本研究の手続きは, は文京学院大学人間学部 倫理委員会の承認を受けて実施された。

\section{結 果}

\section{生理指標}

ケーブルの接続不全, ネットワーク接続の不調によ り 3 名のデータが失われ, 有効サンプル数は 45 と なった。1分未満の短期間のデー夕損失に関しては, 直前の測定值を用いて補完し, 有効データとして用い た。電極の不備等によって明らかな異常值がみとめら
れる部分に関しても, 直前の測定值を用いて適宜修正 を行った。 $\mathrm{SC}$ 変化量は個人差が大きく, また本研究 ではどの期間における変動が大きいのかを参加者ごと に検出する事が重要であるため, 計測期間中の SC を 参加者内でZ変換した。全サンプルの平均值を求めた 結果を図4に示した。

講義期間中，一過性に上昇する場面も見受けられた が, 全体として徐々に下降し, 授業内実験の直前で最 低值となった。授業内実験期間では, 前半で大きな盛 り上がりを見せた後, 0 付近で推移し, 後半で再び上 昇傾向となった。ディスカッション期間では, 開始直 後に大きな上昇を見せ, 終了時まで 0 以上の值を保持 した。各期間におけるZ值に関し, 反復測度デザイン の分散分析を行った。自由度の修正にはHuynh-Feldt の $\varepsilon$ 用いた。期間の効果が有意であった $(F(2,88)=$ $\left.10.15, M S e=.279, \varepsilon=.97, p<.01, \eta_{p}^{2}=.187\right)$ 。さらに Bonferroni法による多重比較を行ったところ, 講義と ディスカッションの間, 授業内実験とディスカッショ ンの間に有意な差が認められた（いずれも $p<.05) 。$

\section{主観報告}

主観評定の平均值と SD, 分散分析および多重比較 を行った結果を表 1 に示した。

“主体的な”，“楽しい”，“活気のある”，“集中した” に関しては, 講義に比べ授業内実験およびディスカッ ション期間で有意に高い值となった。“眠い”，“だる い”，“授業が長く感じた”に関しては，授業内実験お よびディスカッションに比べ, 講義期間で有意に高い 
長野ら：IoT 皮虐コンダクタンス測定器を用いた授業評価

表1。主観報告の平均値及び標準偏差と統計処理結果

\begin{tabular}{|c|c|c|c|c|c|c|c|c|c|}
\hline & 講義 & $\begin{array}{c}\text { 授業内 } \\
\text { 実験 }\end{array}$ & $\begin{array}{c}\text { ディス } \\
\text { カッション }\end{array}$ & $N$ & $F$ & $p$ & MSe & $\eta_{p}^{2}$ & 多重比較結果 \\
\hline 主体的な & $\begin{array}{r}2.51 \\
(0.69)\end{array}$ & $\begin{array}{r}2.70 \\
(1.09)\end{array}$ & $\begin{array}{r}3.21 \\
(0.88)\end{array}$ & 43 & 8.02 & $* *$ & 0.81 & 0.16 & $\begin{array}{l}\text { 講義, 授業内実験 } \\
\text { <ディスカッション }\end{array}$ \\
\hline 興味深いものである & $\begin{array}{r}3.17 \\
(0.90)\end{array}$ & $\begin{array}{r}3.64 \\
(0.90)\end{array}$ & $\begin{array}{r}3.55 \\
(0.91)\end{array}$ & 42 & 4.90 & $*$ & 0.60 & 0.11 & 講義＜授業内実験 \\
\hline 受身な & $\begin{array}{r}3.21 \\
(1.06)\end{array}$ & $\begin{array}{r}2.86 \\
(1.04)\end{array}$ & $\begin{array}{r}2.86 \\
(0.99)\end{array}$ & 42 & 2.10 & ns & 0.95 & 0.05 & \\
\hline 無意味なものである & $\begin{array}{r}2.21 \\
(1.09)\end{array}$ & $\begin{array}{r}2.02 \\
(0.82)\end{array}$ & $\begin{array}{r}1.93 \\
(0.97)\end{array}$ & 43 & 1.41 & ns & 0.65 & 0.03 & \\
\hline 楽しい & $\begin{array}{r}3.07 \\
(0.87)\end{array}$ & $\begin{array}{r}3.58 \\
(1.02)\end{array}$ & $\begin{array}{r}3.70 \\
(0.79)\end{array}$ & 43 & 8.94 & $* *$ & 0.54 & 0.18 & $\begin{array}{l}\text { 講義＜授業内実験, } \\
\text { ディスカッション }\end{array}$ \\
\hline 活気のある & $\begin{array}{r}2.47 \\
(0.84)\end{array}$ & $\begin{array}{r}3.07 \\
(1.11)\end{array}$ & $\begin{array}{r}3.35 \\
(0.89)\end{array}$ & 43 & 10.77 & $* *$ & 0.82 & 0.20 & $\begin{array}{l}\text { 講義＜授業内実験, } \\
\text { ディスカッション }\end{array}$ \\
\hline 集中した & $\begin{array}{r}2.42 \\
(0.95)\end{array}$ & $\begin{array}{r}3.07 \\
(1.13)\end{array}$ & $\begin{array}{r}3.44 \\
(0.95)\end{array}$ & 43 & 16.08 & $* *$ & 0.89 & 0.28 & $\begin{array}{l}\text { 講義＜授業内実験, } \\
\text { ディスカッション }\end{array}$ \\
\hline 眠い & $\begin{array}{r}3.37 \\
(1.41)\end{array}$ & $\begin{array}{r}2.47 \\
(1.30)\end{array}$ & $\begin{array}{r}2.30 \\
(1.15)\end{array}$ & 43 & 12.15 & $* *$ & 1.22 & 0.22 & $\begin{array}{l}\text { 講義＞授業内実験, } \\
\text { デイスカッション }\end{array}$ \\
\hline だるい & $\begin{array}{r}3.07 \\
(1.15)\end{array}$ & $\begin{array}{r}2.58 \\
(1.19)\end{array}$ & $\begin{array}{r}2.42 \\
(1.17)\end{array}$ & 43 & 6.98 & $* *$ & 0.79 & 0.14 & $\begin{array}{l}\text { 講義＞授業内実験, } \\
\text { デイスカッション }\end{array}$ \\
\hline 授業が長く感じた & $\begin{array}{r}2.77 \\
(1.12)\end{array}$ & $\begin{array}{r}2.09 \\
(1.05)\end{array}$ & $\begin{array}{r}2.05 \\
(1.08)\end{array}$ & 43 & 12.08 & $* *$ & 0.58 & 0.22 & $\begin{array}{l}\text { 講義＞授業内実験, } \\
\text { デイスカッション }\end{array}$ \\
\hline
\end{tabular}

( ) 内は標準偏差, ${ }^{*} p<.05,{ }^{* *} p<.01$

值となった。“主体的な”に関しては，ディスカッショ ン期間が他期間に比べ有意に高く、“興味深いもので ある”に関しては, 授業内実験と講義の間のみに差が 見られ，授業内実験が有意に高かった。“受け身な”， “無意味なものである”，に関しては，各期間の間に有 意な差は認められなかった。

\section{相関分析}

$\mathrm{Z}$ 変換された $\mathrm{SC}$ 值の各期間の平均值と対応する期 間の各主観評定值の相関を求めた結果を表 2 に示し た。相関係数算出の際, 生理, 心理双方のデー夕に不 備がない参加者を選出した結果, 有効サンプル数は 37 となった。

講義期間では，SC と主観評定項目の相関は総じて 低く，“受け身な”において有意な弱い相関が見られ るのみであった。授業内実験期間では, “楽しい”,“集 中した”において有意な弱い相関が認められ，“眠い”, “だるい”，においては負の，“活気のある”において
正の相関の可能性が認められた。ディスカッション期 間では，SCと主観評定の間に，有意な相関は認めら れなかった。

デイスカッション結果の抜粋を下記に述べる。テレ ビ CM, 映画の予告, 試写会等, ゲームのデモプレイ で用い, 興味・関心の度合いからコンテンツ評価や開 発の継続, 中止判断に用いる, あるいは音楽のコン クール，打笑いの勝ち抜き戦，スポーツの試合で用 い, MVPや優勝者を決めるなど, エンタテインメン トコンテンツ評価に関するアイデアが多く得られた。 また, 婚活パーティーで用い, 盛り上がりや恋愛感情 の評価に用いることで, 告白しなくても好きな相手が わかり, 結婚可能性が上がるなど, 恋愛・結婚場面へ の応用アイデアも多く得られた。他には, 教育場面へ の応用として, どの時間帯, 授業形式が眠くなりやす いのかを調べ授業内容の改善に役立てる, 年少時より 用いて, 早い段階で適性を見極める, SNS等のソー シャルアプリと連動させ, 集団での意思決定や, 犯罪 
表2. 各条件における皮膚コンダクタンスと主観報告の相関

\begin{tabular}{lccc}
\hline & 講義 & 授業内実験 & ディスカッション \\
\hline 主体的な & -0.04 & 0.21 & -0.09 \\
興味樑いものである & -0.01 & 0.17 & 0.03 \\
受身な & $-0.34^{*}$ & -0.18 & -0.22 \\
無意味なものである & -0.10 & -0.14 & 0.09 \\
楽しい & -0.07 & $0.39^{*}$ & -0.01 \\
活気のある & -0.12 & $0.32^{\dagger}$ & 0.07 \\
集中した & 0.09 & $0.36^{*}$ & 0.08 \\
眠い & -0.13 & $-0.29^{\dagger}$ & -0.08 \\
だるい & -0.05 & $-0.28^{\dagger}$ & 0.09 \\
授業が長く感じた & -0.15 & -0.20 & -0.03 \\
\hline
\end{tabular}

${ }^{\dagger} p<.10,{ }^{*} p<.05$

抑止，自殺予防に役立てるなどのアイデアが得られ た。

\section{考 察}

\section{計測システムの動作状況}

本研究では, 独自に作成された低コストの計測器を 用い，短期間に多くの測定デー夕を取得できた。使用 法をできる限り単純化し, 参加者自身が装着を行った ことで, 比較的多数の参加者であるにもかかわらず, 少数の実験者のみで授業期間内での計測を行う事がで きた。一方で, 計測器が正常に動作している場合にお いても不通期間が散見された。原因の一つとして, 構 造上の問題が考えられた。リセットおよび計測開始久 イッチが外部に露出していたため, 参加者が意図せず 押下し，一定期間測定值が得られなくなってしまう現 象が生じていた可能性があった。別の要因として, 使 用したLTE回線が計測時間帯に混雑し低速になる傾 向があったため, 結果として不通区間が生じた可能性 が考えられた。今回は参加者が計測結果を参照できる ようにするため, デー夕保存をWAN側のサーバーで 行ったが, より正確な計測結果を取得したい場合は, LAN内にサーバーを設置する事でデー夕の損失頻度 を下げる事ができるだろう。

\section{生理指標}

講義期間中, 一過性の上昇を示しつつも, SCのZ 得点は徐々に下降し, 授業内実験開始直前に最低值と
なった。SCは, 実験刺激の新奇性や重要性を反映し 上昇するとの知見 (Barry, 1982; Dindo \& Fowles, 2008) から, 講義中に参加者が新奇性や重要性を感じ 得た部分に，一過性の上昇が生じた可能性が考えられ た。また, SCを始めとする皮膚電気活動は, 睡眠中 に低く, 精神活動の活発化に従い上昇し, 覚醒水準の 指標となることから (本多, 2017), 講義中の SC 低下 は覚醒水準の低下を反映したものと解釈できる。堀 （1986）は, 講義中に6名の受講生の皮膚電位水準を 記録した結果を報告しているが，講義開始から 10一 15分で下降しはじめ, 注意喚起を行った期間のみで 一過性の上昇をみせるものの，30-40分ごろには約 半数の学生が講義開始前レベルを下回ったと報告して いる。本研究においては, 他期間と差別化するため, 講義期間中は教員から何ら注意喚起を行わなかった。 その結果として, 同様もしくはより速やかな覚醒水準 の低下が生じたと考えられた。授業内実験およびディ スカッションでは, いずれも SCは大きく上昇してい るように見受けられたが, 講義と授業内実験の間に有 意な差は認められず, デイスカッションと講義の間に のみ明確な差が見られた。講義および授業内実験が， 教員から学生へ向けた一斉授業方式であるのに対し， ディスカッションは双方向形式であった。学習コンテ ンツの性質が血行力学的反応に与える影響を検討した 野村ら (2011) では, インタラクティブなコンテンッ の場合に, 心拍数の上昇を中心とした, 能動的対処が 見られることを指摘している。心拍数上昇も SC上昇 も交感神経活動の充進を反映したものである。本研究 
においても, 学生どうしのコミュニケーションが能動 的対処を生じ, SC上昇に寄与した可能性が考えられ た。ディスカッションの内容は, 参加者にとって身近 なアイデアが多く見られた。学生達はメンバーの生体 情報を共有しながら, 言い換えれば集団でバイオ フィードバックを受けながらディスカッションを行っ ている状態であり, 生体情報の即時フィードバックが 議論を活性化し, 結果として高いSCを生じた可能性 も考えられた。

\section{主観報告}

授業に対する主観報告は，授業内実験およびディス カッションに対する評定が概ね肯定的であり, 講義へ の評価が全般的に否定的である傾向が見られた。学生 自身がかかわる授業内実験やディスカッションを積極 的に取り入れることで，覚醒状態を上げ，かつ授業に 対する印象も改善する事ができる可能性がある。“興 味深いものである”に関しては授業内実験が，“主体 的な”に関してはディスカッションが，それぞれ特に 高い評価を得た。辻・杉山（2016）によれば，アク ティブラーニング型授業は, 通常形式の授業に比べ, 理解度に差はないものの, 自学自習の意欲が高くなる 特徵があり, 本研究の主観報告も概ね一致した結果で あると言えた。授業内実験は，SCに関しては講義期 間との間に有意差は出ていないものの, 課題内容に応 じて生体反応が刻々と変化する様子を観察することが でき, 実施者の表出行動と生体反応を同時に観察する ことで, 学生たちの興味が強く引き出されたと考えら れる。若年者を対象としたストレスマネジメント教育 においても, 低コスト計測器を多数用いた心身相関体 験実習が，参加者の興味を引き出すことが確認されて いる（長野・吉田, 2018)。実験に参加する学生は少 数であるため, 主体性に関してはディスカッションに 及ばないものの, 学習効果を高める有効な手段となる 可能性が示唆された。

\section{相関分析}

授業内実験においてSCは，“集中した”，“楽しい”， “活気のある”と正の相関あるいはその傾向が認めら れ，“眠い”，“だるい”の項目とは負の相関傾向が認 められた。SCを含む皮膚電気活動は, 睡眠中に低く, 精神的な活動が活発になるにつれて上昇することか
ら，覚醒水準を反映する指標となる(本多，2017）。 “集中した”は高覚醒, “眠い”，“だるい”は低覚醒に 該当するため, これらの項目に相関が認められたこと は妥当である。また，コンピュータ・ゲーム中の主観 的感情と SC変化を検討した伏田・長野 (2015)では, $\mathrm{SC}$ とポジティブ感情の上昇が認められた。授業内実 験課題のゲーム性が “楽しい”, “活気のある”などの 感情を喚起し，SCを高めた可能性がある。一方で, 講義中は”受け身な”と負の相関が認められた以外は, 明確な相関は得られなかった。堀 (1986) は講義中の 皮膚電位水準変化に基づき, 行動観察で判断されるよ りもかなり早くから vigilance低下が生じる可能性を 指摘しており, 阿部 (2017) も, 傾眠に伴い認知, 行 動, パフォーマンス, 自律神経活動等に変化が生じる が，必ずしも眠気の主観的体験を伴わないとしてい る。覚醒水準の低下を主観的に知覚する事は難しく, 結果として主観的体験と SCの相関が低くなる可能性 があるかもしれない。“受け身な”に関しては，他期 間においても有意ではないものの負の相関を維持しい るため, 授業の形式に関わらず受動的態度は低いSC と関連するものと考えられる。他期間に比べディス カッションでは, SC と主観評定の間の相関は総じて 低めであり有意な相関が認められなかった。山崎 （1986）は, 社会的相互場面において, 観衆の存在や, グループ作業が皮膚電位水準を高めるとしている。ま た, 強い不安感情を伴うパニック障害患者は慢性的な $\mathrm{SC}$ 上昇を生じ, 特に対人場面における不安感情は $\mathrm{SC}$ を顕著に上昇させることが示唆されている (Doberenz, et al., 2010; Parente, et al., 2005)。ディスカッション は, 他者とのコミュニケーションが不可欠であり, 一 部参加者において対人不安による顕著な $\mathrm{SC}$ 上昇が生 じ，結果として主観評定との関係が不明瞭になった可 能性が考えられる。この事は, “だるい”と SCの相関 がディスカッションにおいて正に転じていることから も襄付けられる。これらの結果は, 形式の異なる授業 で得られた SCを一様に扱うことの難しさを示唆する ものである。

\section{今後の展望}

生体反応変化は学習者の興味領域の識別や, 学習ス タイルの識別に有効である可能性が示唆されている (董・本間, 1997; 矢島ら, 2012)。学習スタイルとア 
クティブラーニングの関係については, Felder \& Spurlin（2005）の学習スタイル尺度を用いた, 森田ら （2016）に詳しい。反転授業では, 活動的学習者はグ ループによる議論を肯定的に評価したのに対し, 内省 的学習者はグループワークに懐疑的であり, ストレス を感じている可能性が示唆された。一方で, Web ベースの教材では, 内省的学習者の方が学習を効率的 に行うことが確かめられている（森田・Koen, 2006）。 $\mathrm{SC}$ は対人不安を顕著に反映するため, 覚醒度だけで なく各授業形式への適性を評価できるようになる可能 性がある。今後は, コストが低く利便性が高い計測環 境の普及によって, 授業中の覚醒度や授業形式への適 合度を半自動的に評価・蓄積することが可能となり， 対象集団の特質に適した授業形式を迅速に選択し, 学 習効率を向上させられる可能性がある。

\section{謝 辞}

本研究は, 日本学術振興会・科学研究費補助金「挑 戦的研究 (萌芽) 適応的な学習支援を目指した生体情 報計測による学習活動のモニタリング手法の確立（課 題番号 $18 \mathrm{~K} 18670) 」 の 一$ 部として行われた。実験実施 をサポートしてくださった早稲田大学の岡野さん, 文 京学院大学の加藤さんに感謝いたします。

\section{引用文献}

阿部 高志 (2017). 覚醒と眠気の評価法. 堀 忠雄 • 尾崎 久記 (監) 片山順一・鈴木 直人 (編) 生 理心理学と精神生理学 第II巻応用 (pp. 181190）北大路書房

Anderson, C. (2012). Makers: The new industrial revolution. New York: Crown Business. (アンダー ソン，C. 関 美和（訳）(2012). MAKERS—21 世紀の産業革命が始まる NHK出版)

安斎 勇樹・青木 翔子 (2019). ワークショップ実践 者のファシリテーションに打ける困難さの認識 日本教育工学会論文誌, 42, 231-242.

浅野 樹美・中山実・清水 康敬 (1995). ニューラル ネットワークを用いた曈孔応答モデルと動画番組 視聴時への適用 日本教育工学雑誌, 18,61-70.

Barry. R. J. (1982). Novelty and significance effects in the fractionation of phasic OR measures: A synthesis with traditional OR theory. Psychophysiology, 19, 28-35.

Bloom, B. S., Hastings, J. T., \& Madaus, G. F. (1971). Handbook on formative and summative evaluation of student learning. New York: McGraw-Hill.（ブルーム, B. S., ヘスティング ス, J. T., マドゥス, G. F. 梶田 颚一・渋谷 憲 一・藤田 恵需（訳）（1973）。教育評価法ハンド ブック——教科学習の形成的評価と総括的評 価一一第一法規)

董 玉琦・本間 明信 (1997). 理科授業中の子ども個 人の情動変化の夕イプ: 授業中の学習者の情動変 化に関する研究 (3) 日本科学教育学会研究会研 究報告, 11, 29-34.

Dawson, M. E., Schell, A. M., \& Filion, D. L. (2007). The electrodermal system. In J. T. Cacioppo, L. G. Tassinary, \& G. G. Berntson (Eds.), Handbook of psychophysiology (pp. 159-181). New York: Cambridge University Press.

Dindo. L., \& Fowles, D. C. (2008). The skin conductance orienting response to semantic stimuli: Significance can be independent of arousal. Psychophysiology, 45, 111-118.

Doberenz, S., Roth, W. T., Wollburg, E., Breuninger, C., \& Kim, S. (2010). Twenty-four hour skin conductance in panic disorder. Journal of Psychiatric Research, 44, 1137-1147.

Felder, R. M., \& Spurlin, J. (2005) . Applications, reliability and validity of the index of learning style. International Journal of Engineering Education, 21, 103-112.

伏田 幸平・長野 祐一郎 (2015). コンピュータ ・ ゲーム時の競争環境の違いが自律系生理反応にも たらす効果 生理心理学と精神生理学, 33, 181191.

本多麻子 (2017). 発汗 堀 忠雄 - 尾崎 久記 (監) 坂田 省吾 - 山田 冨美男 (編) 生理心理学と精 神生理学 第I巻 基礎 (pp. 207-210) 北大路 書房

本間 明信 (1984). 授業における思考と情動とのかかわ りおよびその集団的相互作用一生理指標として の授業 GSR一 日本教育工学雑誌, 8, 97-106. 
堀忠雄 (1986). 教育場面への適用 新美 良純・鈴 木二郎（編） 皮膚電気活動（pp. 183-191）星 和書店

Irfan, A. C. M., Nomura, S., Yamagishi, T., Kurosawa, Y., Yajima, K., Nakahira, T., ..., Fukumura, Y. (2011). Utilization of bio-signals to understand the physiological states of e-learners and improve the learning contents date of evaluation. IEICE Transactions on Information and Systems, E94-D (6), 1235-1242.

向後 千春 ·冨永 敦子. 石川 奈保子 (2012). 大学に おける eラーニングとグループワークを組み合わ せたブレンド型授業の設計と実践 日本教育工学 会論文誌, 36, 281-290.

美濃 哲郎（1986）。皮膚コンダクタンス水準と皮膚コ ンダクタンス反応 新美 良純・鈴木二郎（編） 皮膚電気活動 (pp. 39-43) 星和書店

三保 紀裕 ・清水 和秋 (2011). 大学進学理由と大学で の学習観の測定一尺度の構成を中心として—— キャリア教育研究, 29, 43-55.

宮西 祐香子・長濱 澄・森田 裕介 (2017). 指尖容積 脈波計測装置による学習活動時のストレス測定と 主観評価の関連分析 日本教育工学会論文誌, $41,149-152$.

溝上 慎一 (2007). アクティブ・ラーニング導入の実 践的課題 名古屋高等教育研究, 7, 269-287.

溝上 慎一 (2014). アクティブラーニングと教授学習 パラダイムの転換 東信堂

森田 裕介・Koen, B. V. (2006). WebベースPSIコー スに扔ける学習過程と学習スタイルとの関連性に 関する一分析 日本教育工学会研究報告集, 6 , $77-80$.

森田 裕介 - 長濱 澄 - 宮西 祐香子 (2016). 反転授業 における学習者の活動と学習者特性の関連につい ての一考察 日本教育工学会研究会報告集, 3, 135-138.

長野 祐一郎 (2012). フィジカルコンピューティング 機器を用いたストレス反応の測定 ストレス科学 研究, $27,80-87$.

長野 祐一郎・吉田 椋 (2018). 低コスト生体計測器 を利用した心身相関体験プログラムの実施 生理 心理学と精神生理学, 36, 53-61.
中山実 - 椎野貴博 - 清水 康敬 (1998). 課題解決時 の鼻部温度変化と課題正答率との関連 電子情報 通信学会論文誌, J81-D-II, 1452-1454.

中山 実・清水 康敬 (2000). 生体情報による学習活 動の評価 日本教育工学会論文誌, 24, 15-23.

西川 純・烟内 誠二 (1998). 相対瞳孔直径差を用い た科学番組への興味・関心の測定の試み 科学教 育研究, 22, 42-46.

野村 収作 - Irfan, C. M. - 山岸 隆雄 - 黒澤 儀将 - 矢 島 邦昭・中平勝子, $\cdots$ 福村 好美 (2011). 血行

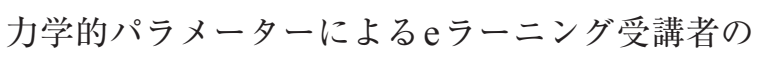
生理評価研究 電気学会論文誌, 131, 146-151.

Parente, A. C. B. V., Garcia-Leal, C., Del-Ben, C. M., Guimaraes, F. S., \& Graeff, F. G. (2005). Subjective and neurovegetative changes in healthy volunteers and panic patients performing simulated public speaking. European Neuropsychopharmacology, 15, 663-671.

櫻井 優太 (2017). 皮膚コンダクタンスを測定する安 価な回路の設計と虚偽検出実験への応用愛知淑 德大学論集心理学部篇, 7, 27-38.

清水 康敬・近藤 俊一・前迫 孝憲・熊谷 龍 (1987). 曈孔面積測定装置の開発と心理的変化に関する一 検討 日本教育工学雑誌, 11, 25-33.

寺尾 敦 (2012). 生理デー夕を用いた学習評価永 岡 慶三・植野 真臣・山内 祐平 (編) 教育工学 選書第 8 巻 教育工学における学習評価 (pp. 128-142）ミネルヴァ書房

辻 義人・杉山 成 (2016). 同一科目を対象としたア クティブラーニング授業の効果検証 日本教育工 学会論文誌, 40, 45-48.

梅沢 章男 (1998). 教育工学と生理心理学 山崎勝 男 - 藤沢 清 - 柿木 昇治 (編) 新生理心理学 3 巻 新しい生理心理学の展望（pp. 250-263） 北大路 書房

矢島邦昭 - 小川信之・高附祐輔 - 野村 収作 - 福 村 好美 (2012). e-learning 受講中の生体情報を 用いたコンテンツの質の評価に関する実験 情報 処理学会研究報告: 教育学習支援情報システム (CLE), 2012-CLE-7 (6), 1-6.

山崎 勝男 (1986). 社会行動 新美 良純・鈴木二郎

（編）皮膚電気活動（pp. 171-182）星和書店 